\title{
EVIDENCE OF THINGS SEEN: UNIVOCATION, VISIBILITY AND REASSURANCE IN POST-REFORMATION POLEMIC
}

\author{
JOSHUA RODDA* \\ University of Nottingham
}

\begin{abstract}
This article reaches out to the audience for controversial religious writing after the English Reformation, by examining the shared language of attainable truth, of clarity and certainty, to be found in Protestant and Catholic examples of the same. It argues that we must consider those aspects of religious controversy that lie simultaneously above and beneath its doctrinal content: the logical forms in which it was framed, and the assumptions writers made about their audiences' needs and responses. Building on the work of Susan Schreiner and others on the notion of certainty through the early Reformation, the article asks how English polemicists exalted and opened up that notion for their readers' benefit, through proclamations of visibility, accessibility and honest dealing. Two case studies are chosen, in order to make a comparison across confessional lines: first, Protestant (and Catholic) reactions against the Jesuit doctrine of equivocation in the late sixteenth and early seventeenth centuries, which emphasized honesty and encouraged fear of hidden meaning; and second, Catholic opposition to the notion of an invisible-or relatively invisible—church. It is argued that the language deployed in opposition to these ideas displays a shared emphasis on the clear, certain, and reliable, and that which might be attained by human means. Projecting the emphases and assertions of these writers onto their audience, and locating it within a contemporary climate, the article thus questions the emphasis historians of religion place on the intangible-on faith-in considering the production and the reception of Reformation controversy.
\end{abstract}

KEY WORDS: Religious controversy, church history, equivocation, certainty, truth

It has been suggested that religious controversy and polemic after the English Reformation might be seen as one-dimensional. Its authors focused on the exclusive, tiresome minutiae of doctrine; they were more concerned with demolishing their adversaries than offering any real assurance to their readership, and the nature of their positions and arguments engendered a mannered process of perpetual and self-perpetuating antagonism. As a result, and despite the intentions behind it, religious controversy bore little relation to the real, personal experience of faith: Michael C. Questier (1996: 12, 13of History at the University of Nottingham. Email: J.Rodda@nottingham.ac.uk. 
23, 35-39), to give one example, has cited both the accessibility and the availability of controversy, only to return to the ultimately distant, and demonstrably circuitous, nature of the arguments involved. For the most part, therefore, reference to the tremendous body of polemical writing that survives for post-Reformation England has been restricted to two areas of enquiry: biographical studies of the divines who produced it, and more intricate examinations of the refinement of particular churches and their doctrinal positions. The audience-who are taken to be inscrutable, save through a study of marginal annotations, works written in response, or a tabulation of printed and manuscript editions-have largely been set to one side. Their experiences when they encountered works of polemic - transformative or not-are often minimized or underexplored. But to maintain this focus and these assumptions would be to underestimate a genre whose profile in research has been steadily growing; one that can tell us a great deal about the expectations of the society in and for which it was produced (Lake 2006: 89-90).

To move into these questions, it is necessary to take something of an interdisciplinary approach, and to examine polemical pamphlets and tractates not as works of academic theology, but as cultural artefacts. In this paper, I will suggest that the most interesting, fruitful aspects of a work of religious polemic lie simultaneously above and beneath its actual doctrinal content. On the one hand, as has been argued for a long while by Peter Lake, Anthony Milton (1995: 4) and others, a greater emphasis must be placed on the intellectual apparatus of religious controversy-the methods of reasoning, of contrast and genre, in which its arguments were framed. On the other, and in tandem with this, we need to go deeper into the casual rhetoric of these works - the passages in between those we would typically underline. What assumptions were polemicists making about their audiences? To what human needs or fears were they appealing? And how did they respond to their readers' expectations? It is in the latter regard that the audience for polemical works might be closer at hand than the paucity of direct evidence has led us to assume, and could well have been more engaged than the style and subject matter of religious controversy might lead us to believe. Addressing these questions will allow us to step beyond the cyclical back-and-forth between antagonists, towards the more positive-and far more interesting-relationship between controversialists and their audience (Questier 1996: 36).

The starting point for this article has been the idea of certainty, and more specifically the articulation and presentation of that idea in controversy and polemic. In this, what follows transposes several of the conclusions of Susan Schreiner on the early European Reformation into a post-Reformation, English context, and further takes a parallel approach to some of the questions raised and answered by Daniel Cheely in an article of 2014. Schreiner (2010: $3,35,205)$ saw the sixteenth and seventeenth centuries as an age transfixed 
by notions of certainty, and haunted by the demonic spectre of doubt and deceit, and this same atmosphere can be pursued in English examples. Cheely (2014: 825-826), meanwhile, has found a necessary and deliberate maintenance of certainty in controversial works, in the face of epistemological scepticism, and describes its invocation in the writings of Robert Bellarmine and William Whitaker as a conflict over the ownership of truth-although less is made here of the needs of a wider audience. In fact, polemicists of every confessional standpoint worked to appeal to a diverse readership through a careful, and occasionally subtle, deployment of the most basic language of certainty, clarity, and manifest or tangible truth. To give an opening and a most direct example, the Protestant lay polemicist Humphrey Lynde (1629: 231, 241, 256-257) laid out testimonies to 'the infallible certaintie of the Protestant faith, and the uncertainty of the Romish', in distinguishing flawed human tradition from the security of scripture. The idea that audiences at this time needed something tangible to hold on to is first evidenced by the fact that polemicists took time out from attacking their confessional opponents in order to give it to them.

To demonstrate this, and the overlap between Catholic and Protestant approaches, this article will focus on two specific areas of dispute: the Protestant reaction against the Jesuit doctrine of equivocation or mental reservation from the end of the sixteenth century, and the Catholics' assertion of institutional visibility and succession through the first half of the seventeenth. This is, in itself, something of a departure. Equivocation has previously been a concern for literary theorists as much as for historians, and historical studies of the doctrine have for the most part focused on its legal aspects, and questions of loyalty, Catholic identity and the role of the state in the climate surrounding the Gunpowder Plot and subsequent Oath of Allegiance. The linguistic nature of this defensive doctrine-which allowed for the presentation of ambiguous or truncated testimony, whilst retaining the whole and perfect meaning in one's mind-has appealed to those with an eye to the period's dramatic output, as has its prominence in the popular imagination (Huntley 1964: 390-400; Baynham 2006: 101-112; Wake 2011: 941-960). For historians of law, religion, and the church (Halley 1991: 33-52; Carrafiello 1993: 671-680; Houliston 2007: 17-18, 145, 148), the circumstances of that prominence, through the trials of the Jesuits Robert Southwell in 1595 and Henry Garnet in 1606 (in the immediate context of the Plot), along with the dissemination of $A$ Treatise of Equivocation, or the Treatise against Lying and Fraudulent Dissimulation (Anon 1851: iii-xviii), have drawn analysis away from the nature of the doctrine, towards its application and ramifications.

The language of Protestant counter-arguments has rarely been subject to close analysis, but in those instances where it has, the importance of palpable truth, of certainty, is already visible. In discussing the trial of Southwell, Janet 
Halley (1991: 41) has suggested that the Jesuit's maintenance of equivocation did not provoke outright denunciation so much as a dialectic joust over clarity of meaning, of ownership of the truth: equivocation was 'a bid for the control of language and the social production of meaning'. The same was to happen after the trial of Garnet_all sides trying, as Paul Wake (2011: 942, 950) has indicated, to put words and truth back together. In Wake's dramatic reading, equivocation had overthrown language, and put truth at a new and terrifying distance. Doubt had been instilled. Now, for the sake of confessional discourse and personal religious assurance, it had to be purged.

Attacks on equivocation and mental reservation stemmed from popular fears of the hidden; of uncertainty and deception. The Society of Jesus was particularly associated with the practice following the trials of Garnet and Southwell: encountering a disguised Jesuit at dinner in 1626, the chaplain Daniel Featley (1630: 239-240) was reported to have said: 'I perceive you are not onely a Priest, but a Jesuited Priest also. For you can equivocate.' Those of the Society are deemed untrustworthy as a result (Featley 1624: X2*v; Marotti 2005: 51; Walsham 2009: 42). In a sermon at court following the Gunpowder Plot, John King (1608: 27, and see Persons 1609: 674-675) asked 'what hope of truth or simplicity from these or their impes[?]'. Featley (1624: $\mathrm{A} 2^{\mathrm{r}}$ ), in the midst of a printed dispute with the Jesuit John Percy (alias Fisher), would write 'let them be gulled or deceived', of anyone who might trust 'the Jesuites... who maintaine, that a man may utter an untruth in words without the guilt of Veniall sinne, so hee be sure to make it up by a mentall reservation'.

In a work of 1607 , directed 'to both sorts, as well Univo-catholique, as Equivo-catholique Readers', the Jesuits are deemed 'halfe tongued, hollow hearted' (Univocè-Catholicus 1607: $\mathrm{A} 3^{\mathrm{r}-\mathrm{v}}$ ). In a hundred such, William Fennor (1612: 24) asserted, 'there are scarce two just dealing men'. For Richard Harris (1614: 298), opposing the Jesuit Martin Becanus in 1612-14, more truth could be found in 'savage $\xi$ wilde robbers, [than] in these... which teach $\&$ practice the Art of Equivocation', and George Abbot, whilst serving as archbishop of Canterbury, applied this theme directly to the question of correct, certain doctrine: 'They would seeme to teach onely the truth, yet deliver doctrinally the art of lying... under the name of equivocation' (Pagitt 1635: Ii3 $^{\mathrm{v}}$ ). Similarly, the controversial college head Thomas Anyan (1615: 13) proclaimed: "Far be it... from us to joine with them in truth of doctrine, that maintaine Equivocating and forswearing... who make an equivocating lye a doctrine'. In light of the practice, Popery was 'a doctrine composed of Lies' (Featley 1624: $\mathrm{A}^{\mathrm{r}}$ ).

More crucially, Thomas Morton (1610: 126), in a longer, printed dispute with the Jesuit Robert Persons, found 'some oddes betweene the honestie of Protestants, and Romanists', demonstrated by the practice, as did a defence 
of Featley printed in 1634: 'a Protestant hath more reason to be beleeved on his bare word, [than] a Papist, because the Protestants Religion tyes him to speake the truth from his heart, without any mentall reservation; but the Papists doctrine teacheth him a pretty kinde of deceipt called Equivocation' (Waferer 1634: 97). Robert Horne (1614: Q2') found the practice in 'odious opposition to Christian plainenesse' - a turn of phrase to which we shall return. At the heart of these assertions is not just the familiar depiction of Rome as a false church, but an image of it as the last place one should venture to find certainty. In the $1640 \mathrm{~s}$, this was to be spelled out in verse by the virulent polemicist William Prynne (1642: 111-112), and printed for wide circulation:

All Rome for a false Church should damne, flye, hate,

Because she teacheth to equivocate;

The worst of all Lies, cheates, that is; no truth

Can be in Rome, who this defends, pursu'th.

How can men pin their faith on Romes Church sleeve,

Whose doubling faith, words, oathes none can beleeve.

Prynne's tarring of the Roman Church with the broad brush of equivocation appealed directly to the need for firm ground; for assurance. Similarly, Anthony Wotton (1608: 15-16) had argued at the height of the equivocation controversy that the unlearned could find no 'sound foundation' in the words of a priest, grounding his point entirely on the doctrine: 'Have I not, trow you, a sound foundation, to build my faith upon, when I have the word of these equivocating traitours, Priests and Jesuits? And yet this is the most I can have in this case, if I be a man unlearned.' The convert Richard Sheldon (1612: 137-140) proclaimed that there was 'no great cause for Comfort' in those who professed the doctrine, and he cited it as 'no small Motive' for his own conversion, whilst presenting it as a warning to others.

So far, so antagonistic. So negative. But there was also a positive mirror to this approach. As well as decrying equivocation as the symptom of Catholic deceit, Protestant writers constructed an image of a grounded and reliable clarity and rationality, against which they could oppose it. Historians have begun to revisit the role of reason-as it was perceived by contemporariesin religious polemic, and more broadly the extent to which we can place our conclusions within the rationality of the period, but the link between discernible reason and confessional reassurance deserves greater attention (Coffey and Chapman 2009: 2-5, 11-14, 16-17; Questier 1996: 16). Peter Lake (1989: $74,77)$ has suggested that Protestants saw their faith as having a greater logical consistency than Catholicism, as opposed to the illusory, superficially reassuring doctrines of popery, and this view, confirmed in Morton and Featley, was itself an effort to offer comfort and sure ground, building on the foundation of certainty to be found in Scripture. On this theme, Thomas 
Beard (1616: 43) argued that equivocation itself, as a doctrine, ought to be subjected to 'common sense and reason': tested by scripture, and by the authority of fathers and heathen philosophers.

The origins of equivocation lay in an Aristotelian fallacy. As this has been defined by Christopher Kirwan (1979: 44): 'When a speaker or writer equivocates, he uses a single expression, more exactly a single phoneme or morpheme, to mean two things.' This is built upon Aristotle's definition of equivocation as 'a fault in a piece of reasoning when each of the meanings between which the reasoner equivocates justifies a part of his reasoning but no one of them justifies the whole' (Kirwan 1979: 36, and see Whitaker 1606: 279; Featley 1624: $\mathrm{V}^{* \mathrm{r}}$; Maloney 1984: 86). This is opposed to the construction of sound arguments, and to the attainment of whole and defensible truth: but on top of this, the term had, through the course of the Jesuit controversies of the sixteenth and seventeenth centuries, undergone a redefinition by intent and morality, which produced such interpretations as the following, from a linguistic guide of 1621 (B 1621: G2v):

Equivocate. To speak or answer with a secret meaning reserved in ones owne mind; which peradventure the hearers do not understand.

Equivocation. A speech or answer made, with a secret meaning reserved in ones mind.

The Aristotelian flaw in argument was not, however, forgotten, as this final entry shows:

Equivocke. When one word signifieth two things.

In fact, the original definition-of double interpretation, ambiguities and multiple answers-had a role to play in the controversy (Halley 1991: 35; Carrafiello 1993: 672-673). Although Morton (1605: 43) scoffed that the Jesuits 'unproperly' used the term for mental reservation, and other writers described its 'abuse' by the Society (James 1612: 17; Wake 2011: 944) the two definitions were further connected in Protestant minds by the lack of a clear, identifiable meaning; the impossibility of reasoned argument. Thus, to rely on those who approved the practice was not only to open oneself up to deceit, but to wander into new possibilities of formal error and, consequently, uncertainty.

By its first definition, equivocation signified an ambiguity that demanded a clear, logical distinction to approach the truth: the Jesuit Michael Walpole (1613: 27) described it in passing — though at the height of the controversyas 'a vice in arguing', and commended those who 'findeth it out'; Francis Bacon (1605: Oo3 ${ }^{\mathrm{r}}$ ) described such ambiguity in expression as the reason for all formal logic. For Protestants, the concept of mental reservation only amplified this problem, by suggesting a multitude of entirely hidden reasons 
that could never be brought to trial. Featley and George Walker, vocal proponents of anti-Catholic disputation in the 1620 s, presented equivocation as the antithesis of reasoned debate- a fault in Catholic argument, and a fundamental flaw in Jesuit disputants. Walker (1641: 29) accuses one adversary in a printed dispute of 'speaking ambiguously, a speech which may beare divers senses; which Logick abhorres in a disputation', whilst Featley (1624: $\mathrm{Ee}^{v}$ ) tells his Jesuit respondent: 'You say, I am bound to dispute in your sense. What sense mean you? The sense that is to be made of your words, or the sense which you make by your mental reservation?... am I therefore to dispute in your non-sence?'

Another former antagonist of the Jesuit Percy, Henry Rogers (1638: 1-2), was to spell this objection out: 'You know that no disputation may be undertaken, no Argument framed... not so much as one bare Proposition, or Sentence may subsist with aquivocation, and amphibologie, words or sentences of double signification, and doubtfull sense untill they be cleared by explications, and distinctions.' More broadly, equivocation and mental reservation are called out as 'solæcismes in reason, much more absurd in conscience \& Christianity' (Ireland 1610: F2v). It should be remembered that for all the emphasis historians have placed on the intangible nature of faith, and the role of divine revelation in conversion, polemicists on both sides spent an inordinate amount of effort trying to prove their points of controversy. The Protestant reaction against equivocation formed part of this approach, and speaks to a need not only for assurance, but for an absolute, demonstrable certainty. Wotton (1608: 16) follows his expression of doubt in equivocating priests with the following: 'Were it not a directer, and certainer course, to hold nothing for truth in religion, but that which is proved to us by plaine testimonies of Scripture, or certaine consequence of reason, drawne from principles evidently exprest, or appare[n]tly contained in the knowne word of God?'

Building on this rational confidence, equivocation in the Catholic clergy was twinned with a lack of discernment in their audience: as Professor Lake (1989: 75, 77) finds in Protestant polemic, Catholic 'illusion and trickery' went hand in hand with 'ignorance and credulity in the laity' (see Harlowe 1641: 23). Thus did Thomas Blundeville (1599: 164) produce a guide to logic for those who would not make it into the universities, because-he saidlogic was an essential help 'to defend the truth of Gods Word' and oppose heresy: a work that contains a passage on the fallacy of equivocation. To take Lake's view (1989: 73) on the dialectic or binary construction of reformed polemic, confidence in knowledge and in the formal, logical demonstration of truth thus stood on the correct side of the division-it was polemically, as well as philosophically, appropriate-and thus the reasoned search for truth through human endeavour could be presented as a godly alternative to the 
deceptive comforts of the Roman Church. For Protestant and moderate puritan writers, therefore, even the most intricate and complex of scholastic discussions, and perhaps especially these, had an eye towards a wide, uncertain, unlearned and godly audience.

But the equivocation controversy also prompted Catholic reactions, partly-but not exclusively-in the context of disputes between the Jesuits and the English secular clergy (James 1612: 16-18; Featley 1644: 23). During the confrontation between secular and Jesuit priests at Wisbech Castle in 1601_and in the aftermath of Southwell_Christopher Bagshaw (1601: 73, and see Huntley 1964: 395) marvelled at how the Jesuits 'are so delighted with equivocation, or a subtile and dissembling kind of speech, as that to the scandall of others they are not ashamed to defend it in their publick writings... it is come to that passe, that though they sweare, men will not beleeve them.' More significant, however, are the qualifications, and outright oppositions, offered by Jesuit writers themselves: because these show precisely the same concern with clarity and attainable certainty found in Protestant reactions. In his exchanges with Morton, Robert Persons (1607: 277-278) restated the need for truth and honest dealing in all but the most dire of circumstances, placing emphasis on constancy and sincerity. Mental reservation had been defended with reference to Aristotle's notion of mixed propositions: an internal expression occurring in the presence of heretical examiners (but audible only to the speaker and to God) need not prejudice truth, or natural reason, or logical progression. Moreover, and more crucially, equivocation was never to be used in matters of faith, particularly in giving comfort or delivering doctrine (Halley 1991: 37, 42; Carrafiello 1993: 676-677; Houliston 2007: 169-170). Persons (1607: 488) is also quite naturally eager to separate the argument over equivocation from doctrinal difference, and Catholics from the language of equivocation itself: 'In matters of controversy our writers shall never be found guylty in these kyndes of false lying \& malicious equivocatio[n]s, where not only untruth is uttered, but it is wittingly also uttered.'

The manuscript Treatise of Equivocation, which had rekindled the controversy after the Gunpowder Plot, had established this same point (Anon 1851: 58), through the language of personal profession- in matters of fayth and religion we must neither denye nor blushe at our Saviour'. In offering assurances, it combines this protection or ring fencing of doctrine with a protestation of underlying honesty and clarity (Anon 1851: 54-55):

there is a certaine vertewe, [which] not onely Catholicke Devynes but the heathen Phylosophers them selves have required in a mans lyfe, [which] is called veretye; not in that strict signification wherby it signifyeth that condition of [our] speech [which] is that it be trewe, but as it signifyeth a generall disposition of the mynde, wherby a man as well in speech as in action, and generally in his whole lyfe, 
[with]out equivocation or dissembling, sheweth hym selfe such as verely he is, and neither more nor lesse.

As this virtue demands, the Treatise maintains (Anon 1851: 56), "we are bounde to deale syncerely and playnely'. Its reference to the heathen philosophers, moreover, points readers back towards that realm of rational demonstration and discourse - of collective, 'Christian plainenesse'- to which Protestant writers were staking their own claim. The language here is reminiscent of Augustine, as well as matching Protestant objections to equivocation (Morton 1610: 114). Persons (1607: 486; 1609: 678) was to build on this spirit in attacking implied Protestant cases of what he would call equivocation; of ambiguity, double-dealing or mental reservation in matters of faith: 'As for example: If a preacher in England who in deed is no Protestant in harte, should preach Protesta[n]t doctrine that is false, and himselfe should thinke it also to be false (as divers perhaps doe) this were to Equivocate both falsely and formally, which is the worst kynd of lying Equivocation that may be'. The Protestants follow their own flawed judgement and self-interest on the truth of the church, but 'they cry out against Equivocation, \& such as do maintayne the same' (Persons 1612: (i) $3^{\mathrm{v}}$-(i) $4^{\mathrm{r}}$ ).

For Catholic writers, this need to present truth, and to offer certainty and assurance to their audience, found clearest expression in statements on the pastoral, validating role of the visible, institutional church. This is, of course, to be expected: the turn towards visibility, for reasons of both spiritual assurance and polemical necessity, has been discussed in terrific detail (Milton 1995: 270-321; Questier 1996: 23-33). However, the language used in this was markedly similar to that found in the equivocation controversy. Building on Protestant claims to an 'invisible' succession through times of persecution or corruption, and taking this to its logical extreme, Catholic writers instead emphasized the role of the church in protection from doubt: it was the guarantor against false or private interpretations of scripture; it represented 'the piller, and ground of Truth' (G 1619: 88-89; Schreiner 2010: 187). As Schreiner (2010: 137, 165) observes, certainty was to be found in the spirit, and the spirit, for Catholics, in the church.

For this reason, as Michael Questier (1996: 25, 27, 30; see Schreiner 2010: 161, 195; Persons 1585: $\mathrm{d} 2^{\mathrm{v}}-\mathrm{d} 3^{\mathrm{r}}$ ) has stated, the clear and certain identification of the church was the means to attain a broader certainty: without it, there was a constant danger of deception and doubt. Thus, in opposition to Protestant invocations of abstracted, syllogistic reasoning-themselves seen as a flawed reliance on private interpretation-the determination of the church was held up as the preventative to endless doctrinal wrangling. However, like the Protestants' attacks on equivocation, these reactions against invisibility were directed to a broad and mixed audience: they were phrased within the need for rational coherence and a firm foundation; for a practical,

PERICHORESIS 13.1 (2015) 
at times surprisingly worldly method onto which both learned and unlearned communicants could pin their faith (Milton 1995: 271). In offering the lay polemicist Humphrey Lynde a 'paire of spectacles', the Catholic John Floyd (1631: b2 ${ }^{\mathrm{v}}-\mathrm{b} 3^{\mathrm{r}}$ ) argued that it was 'the right way, like a wise man and a good scholar', to seek the physical, visible church as the route to correct doctrine:

to find out the Doctrine, which is a thing more spirituall and lesse subject to the sense, by that which is corporall and more subject to the view of all sorts of men. For this is the way that all Scholars, in the teaching of all Sciences take, to wit, to beginne with that which is knowne and evident, and by it to come to the knowledge of that which is hidden, according to Aristotel's Doctrine.

Percy would describe the Protestant reliance on inferences from scripture as an 'appeale from light to darkenes' (Fisher 1626: $\mathrm{Mm}^{\mathrm{v}}$ ), whereas clarity-or to put it another way, 'plainenesse' - was the true path. Further, the missionary priest and polemicist Richard Broughton was to describe visibility itself as a rational proposition, whilst the notion of an invisible church was not 'secure for anie man to venture his salvation upon' (B 1632: 30-31, 32-34). This accepted, the role of the church was then to give comfort, and to offer a clear dissemination of the truth. It provided clarity and resolution to the unlearned: freedom, in the words of the Jesuit Percy, 'from wavering in uncertainty and doubtfulnes' (C 1626: *2v ).

The language of comfort and sure ground-of a 'sound foundation'-is again prevalent here. In his early responses to Luther, Thomas More had emphasized 'safety' and 'refuge', and similar themes persisted (Schreiner 2010: 181, 183, 195). Percy would repeat an argument on the Roman Church that 'we may securely follow her directions and rest in her Judgement' (Fisher 1626: 90). In 1632, Broughton was to repeat St Augustine's emphasis on the 'comfort and societie' to be found in outward signs (B 1632: 30-31). It is remarkable that both equivocation and invisibility would lead their detractors back to Augustine's community of discourse and his elevation of collective wisdom and authority: the minister Henry Burton (1629: 103), contrasted 'St Augustines sincerity' with 'the Councell of Trents double dealing equivocation'. But on the point of visibility, rather than collective enquiry, Catholics rested on mutual assurance. The Jesuit Sylvester Norris invoked 'dependence' on the church, as a requirement to faith and a preventative against heresy (N 1621: 6). For John Pickford (1618: 35), the visible church assured the 'savegarde of little children which may be seduced by me[n] from the manifest clearnes of the truth'. In all of this, the invisible, Protestant line was both hidden and dangerous; a denial of Christ, itself in 'opposition to Christian plainenesse'.

And again, just as Catholics asserted evident truth in the face of the equivocation controversy, in this later exchange Protestant writers were torn be- 
tween holding ground and offering their own language of safety and reassurance, through logical constructs aimed at proving consistent doctrine, or in attempts at producing their own demonstrable succession. Whilst some, like Featley and the Scottish preacher Patrick Forbes (1613: 138), tried to use old, reasoned methods to push back against the visibility argument (suggesting that it was itself concluded by a form of 'æquivocation'), the later and lingering reply was to present a visible Protestant alternative through the early church and those hidden sects that had escaped Catholic corruptions. The true church, clear to God and the elect, was set aside from visible institutions, but was also traced by an increasing number of divines through a revised history (Milton 1995: 278-281; Questier 1996: 31-35).

Though there were differences in emphasis (and outright disagreements) over these methods, it can be argued that they took aim at a consistent target: the concerns of the audience. For some divines, the hidden church of the elect and the visible remnant reinforced one another, as the ideal and the promise, within the assumed and asserted logical cohesion of Protestantism: Catholic visibility, in this synthesis, was simply another, more powerful form of deception; a distraction from the true, doctrinal hierarchy found elsewhere (see Featley 1624: B3 ${ }^{\mathrm{v}}-\mathrm{B} 4^{\mathrm{r}}, \mathrm{C} 3^{\mathrm{v}}, \mathrm{D} 4^{\mathrm{r}}, \mathrm{S} 2^{* \mathrm{v}}-\mathrm{T}^{* \mathrm{r}}$ ). In attempting to combine these approaches, arguing that Protestant visibility since Christ was demonstrated by correct doctrine, Humphrey Lynde (1629: 241-242) maintained that this true practice was 'safe and comfortable, for the beleefe of every Christian, and the salvation of the beleever'. The intention was to prevent fears and accusations of dangerous uncertainty, and this model was contrasted against a Catholic Church that was but a human manipulation of the word of God: a deception, dangerously open to error (Milton 1995: 297; Questier 1996: 25). The same intent can be seen in the opening up of the Protestant succession from the later 1620s (Milton 1995: 306-308). In the judgment of the Catholic Broughton, this effort to construct a visible succession for the reformed church was itself a construct, made because the Protestants found their concept of invisibility-in his own words-'not so plausible to their auditors as they could wish' (B 1632: 35). But at the same time the Jesuit Percy still maintained that visibility was the most plausible and best help to the unlearned (C 1623: 27, 61, 63). This conflict and concurrence of language and approaches speaks to the need for tangible certainty experienced on all sides. Absolutes, pillars, were being put forward.

At the heart of these claims and counter-claims was the seemingly inextricable link between clear, attainable truth and divine authority. As Schreiner (2010: 165, 200) argues, the comfort Catholics located in the visible church was based on divine providence, and Christ's promise in Matthew 28:20. The church was 'grounded in the perfection of Christs divine providence \& mercie' (B 1632: 35); and so, in the words of Pickford (1618: 35), 'why fearest 
thou least the skie should fall?' The object of faith is, in this manner, obvious. During the equivocation controversy, Persons (1607: 299) downplayed the significance of the doctrine with the assertion that God is truth it selfe, and the fountaine of all truth and sincerity': in maintaining mental reservation, it was the ability of this fount to hear the hidden portion of one's statements, combined with Aristotle's mixed propositions, that helped Catholic writers to present a suitable defence, that neither denied one's own profession nor strayed into the sin of a lie. God could neither deceive nor be deceived. But, of course, the distance between deception and the divine was cited ad infinitum on the other side of the equivocation debate: Thomas Sanderson (1611: 78) has the person of Christ decrying the practice: 'Will yee then remember how I cannot but detest your popish equivocation, and mentall reservation? which is nothing else but flat lying \& hypocrisie.' In a sermon of 1616, printed two years later, John Squire (1618: 7-8) cited Proverbs 12:22, and tied equivocation into its condemnation. For Arthur Lake (1640: 30), 'God doth not, he cannot lye; God is not, he cannot be deceived. Therefore the highest commendation of a good man is, that hee speakes... without equivocation or mentall reservation'. God's word, he adds for good measure, 'is tryed to the uttermost' (Lake 1640: 91). The subject of both controversies is ownership over the infallible guarantor of truth and the reliable ground of reassurance; instruction to the audience as to whither they should turn.

Assertions such as these were matched by the connections drawn between invisibility and deceit, uncertainty and doubt, and the threat of the devil. To Morton (1610: 126), equivocation was a 'devilish Doctrine'; to Thomas Bell (1608: 10), 'diabolicall'. It was 'Don Beel-zebub' who was 'the mint-master of equivocation and forgerie', and first taught it to the Jesuits (Boys 1613: 71, and see Huntley 1964: 393, 397). In a sermon preached before King James, and printed in 1608, the young clergyman Thomas Walkington (1608: 47) maintained: 'We must in speaking utter the truth without all sophistrie and equivocation: for this proceedes from the devill the father of lies'; and urged 'the words of truth, information, reformation, consolation, salvation, such as doe inchaunt, and captivate the spirituall eare'. Plain speaking, natural reason, knowledge and divine truth are wrapped up together here; part of one contingent, Christian mode of expression. Equivocation transcends the wit of heathens and 'the practice of Devils' (B 1622: 16-17): it denies clarity and reason, denies the example of Christ, and is cause for doubt and distrust. Thus the characterisation of equivocation as 'Satanicall and damnable' is noted by Persons (1609: 108, and see Carrafiello 1993: 671) as a frequent response from Morton. To Samuel Harsnett (1603: 164), equivocation was a 'new Jesuitical, and old diabolicall tricke'; to Robert Bolton (1611: 54), it was a 'cursed poison'; 'the divels old imposture in Oracles'. But the devil was also 
equated by Catholics with the doubt and discomfort that would result from invisibility (Schreiner 2010: 35, 277, 302).

This has been an early, exploratory effort. Schreiner (2010: 204) draws the point from Thomas More that if a belief or doctrine left one uncertain, then it was, by definition, false', and the following century's emphasis on attainable certainty, visibility and tangible evidence in opposition to deceit and doubt, can be seen in other doctrinal points. Persons (1607: 317) finds equivocation in the Protestant interpretation of hoc est corpus meum - an interpretation 'far different from that naturall plaine and common signification, which all Catholicks hold'. The ministers Henry Burton (1626: 71-72) and Peter Lily (1619: 22-23) both saw the fallacy in the Catholic doctrine of justification. The point to be made here, however, is that we must continue to reconsider how we use the foundational language of polemic, in order to get the most from such efforts-in this case, to understand how they worked to govern the anxieties of their readership, and of the audience gained through printed or vocal delivery. Attainable certainty was a powerful force: Persons' Christian Directory of 1582 is cited by Questier (1996: 37-39) as a prime instrument of persuasion because it was a departure from polemic and controversy, moving the reader through the language of a good life; but this work too had chapters inserted, in the 1585 edition, on points of Christian certainty (at the calumniations of the book's detractors) and-in Persons' words $\left(1585\right.$ : $\left.\mathrm{d}^{\mathrm{v}}-\mathrm{d} 2^{\mathrm{r}}\right)$ on 'matters more plausible' (for those wavering, afraid to engage).

Plausibility, clarity and 'Christian plainenesse': these points were not absent from the controversial field; and indeed, it may be said that the true, linguistic essence of polemic was closer to the 'essence of conversion' Questier posits (1996: 37) than the intricacies of doctrinal argument would lead us to assume. We need to recognize that below these circuitries of doctrine, there were more fundamental stances and actions being pursued-the clarity and availability of these works is matched by an accessibility in method and language (Questier, 1996: 13-14). As a result, the readers are not an unreachable body, disconnected from the arguments produced. In fact, the greater part of post-Reformation polemic was directed to their needs. The principal Catholic defence on equivocation was reserved meaning and identity in the face of incompetent judges. For Protestants, in the matter of the church, meaning and identity are further reserved: they are restricted to the elect, and to be sought in scripture. The Protestant position is that no judge is competent but God; the Catholic is that only God needs hear a whole, absolute truth.

But where did these doctrines, both of them founded in persecution (Houliston 2007: 170), leave their readership? Quite simply, in need of reassurance. In need of fair dealing from their fellow man; a full hearing, natural reason, and scriptural proof. Or in need of security, guidance; somewhere tangible to put their faith. In a culture still dominated by the visual, a polity 
increasingly terrified by the spectre of duplicity, and a society not yet emerged from the anxieties of material subsistence, neither side was likely to win converts by proclaiming the abstract and the unattainable: the invisible was necessarily a cause for unease. Our focus in studying religious controversy thus needs to shift from the cyclical deconstruction of opposing doctrines, which indeed left very little in its path, to the construction of something positive, that a mixed readership could hold onto. The persistent focus of polemicists on clarity, visibility and evidence can open this area up. At the least, it questions our assumption that the best instrument in controversial writing was the evidence of things not seen.

\section{Bibliography}

Anon (1851) A Treatise against Lying and Fraudulent Dissimulation. In Jardine D (ed) A Treatise of Equivocation. London: Longman, Brown, Green, and Longmans.

Anyan T (1615) A Sermon Preached at Saint Marie Spittle April. 10. 1615. Oxford: Joseph Barnes.

B J (1621) An English Expositor: Teaching the Interpretation of the Hardest Words Used in our Language. London: John Legatt.

B R (1622) The Boy of Bilson. London: Felix Kingston.

B R (1632) The Conviction of Noveltie, and Defense of Antiquitie. Douai: Apud viduam Marci Wyonis.

Bacon F (1605) The Twoo Bookes of Francis Bacon, volume 2. London: Thomas Purfoot and Thomas Creede.

Bagshaw C (1601) A True Relation of the Faction begun at Wisbich by Fa. Edmonds, alias Weston, a Jesuite, 1595. and Continued Since by Fa. Walley, alias Garnet, the Provincall of the Jesuits in England, and by Fa. Parsons in Rome, with their Adherents: against Us the Secular Priests their Brethren and Fellow Prisoners, that Disliked of Novelties, and Thought it Dishonourable to the Auncient Ecclesiasticall Discipline of the Catholike Church, that Secular Priests should be Governed by Jesuits. London: Felix Kingston.

Baynham M (2006) 'Twice Done and then Done Double': Equivocation and the Catholic Recusant Hostess in Shakespeare's Macbeth. In Burgess G, Wymer R, and Lawrence J (eds) The Accession of James I. Basingstoke: Palgrave Macmillan, pp. 101-112.

Beard T (1616) A Retractive from the Romish Religion: Contayning Thirteene Forcible Motives, Disswading from Communion with the Church of Rome. London: William Stansby.

Bell T (1608) The Jesuites Antepast, Conteining, a Reply against a Pretensed Aunswere to the Downe-fall of Poperie, Lately Published by a Masked Jesuite Robert Parsons by Name, though he Hide Himselfe Covertly under the Letters of S.R. which May Fitly be Interpreted (a Sawcy Rebell). London: William Jaggard. 
Blundeville T (1599) The Art of Logike. London: John Windet.

Bolton R (1611) A Discourse about the State of True Happinesse: Delivered in Certaine Sermons in Oxford, and at Pauls Crosse. London: Felix Kingston.

Boys J (1613) The Autumne Part from the Twelfth Sundy after Trinitie, to the Last of the Whole Yeere. London: Melchisedech Bradwood.

Burton H (1626) A Plea to an Appeale: Traversed Dialogue Wise. London: W Jones.

Burton H (1629) Truth's Triumph Over Trent. London: Robert Young.

C A (1623) An Answer to a Pamphlet, Intituled: The Fisher Catched in his Owne Net. London: Peter Smith and St Omer, at the English College Press.

C A (1626) True Relations of Sundry Conferences had between Certaine Protestant Doctours and a Jesuite called M. Fisher (then Prisoner in London for the Catholique Fayth:) Togeather with Defences of the Same. St Omer: English College Press.

Carrafiello ML (1993) Robert Parsons and Equivocation, 1606-1610. The Catholic Historical Review 79(4): 671-680.

Cheely D (2014) 'Can It Be that a Sole Authority Remains?' Epistemological Conundrums in Port-Reformation Polemic. The European Legacy: Toward New Paradigms 19(7): 819-832.

Coffey J and Chapman A (2009) Introduction: Intellectual History and the Return of Religion. In Chapman A, Coffey J, and Gregory BS (eds) Seeing Things Their Way: Intellectual History and the Return of Religion. Notre Dame, IN: University of Notre Dame Press, pp. 1-23.

Featley D (1624) The Romish Fisher Caught and Held in his Owne Net. London: Humphrey Lownes.

Featley D (1630) The Grand Sacrilege of the Church of Rome, in Taking Away the Sacred Cup from the Laiety at the Lords Table: Detected, and Convinced by the Evidence of Holy Scripture, and Testimonies of All Ages Successively from the First Propagation of the Catholike Christian Faith to this Present. London: Felix Kingston.

Featley D (1644) Roma Ruens, Romes Ruine: being a Succinct Answer to a Popish Challenge. London: Thomas Purslowe.

Fennor W (1612) Pluto his Travailes, or, The Divels Pilgrimage to the Colledge of Jesuites. London: Nicholas Okes.

Fisher J (1626) The Answere unto the Nine Points of Controversy, Proposed by our Late Soveraygne (of Famous Memory) unto M. Fisher of the Society of Jesus. St Omer: English College Press.

Floyd J (1631) A Paire of Spectacles for Sir Humfrey Linde to See his Way withall. Rouen: [widow of Nicholas Courant?].

Forbes P (1613) An Exquisite Commentarie upon the Revelation of Saint John. London: W Hall.

PERICHORESIS $13.1(2015)$ 
G A (1619) The Widdowes Mite, Cast into the Treasure-house of the Prerogatives, and Prayses of our B. Lady, the Immaculate, and Most Glorious Virgin Mary, the Mother of God. St Omer: English College Press.

Halley JE (1991) Equivocation and the Legal Conflict over Religious Identity in Early Modern England. Yale Journal of Law and the Humanities 3: 33-52.

Harlowe P (1641) A Detection or, Discovery of a Notable Fraud Committed by R. B. a Seminary Priest of Rome, upon Two of the Articles of the Church of England. London: E Purslowe.

Harris R (1614) The English Concord in Answer to Becane's English Jarre: Together with a Reply to Becan's Examen of the English Concord. London: Humphrey Lownes.

Harsnett S (1603) A Declaration of Egregious Popish Impostures, to With-draw the Harts of Her Majesties Subjects from their Allegeance, and from the Truth of Christian Religion Professed in England, under the Pretence of Casting out Devils. London: James Roberts.

Horne R (1614) The Christian Governor, in the Common-wealth, and Private Families Described by David, in his 101. Psalme. Guiding all Men in a Right Course to Heaven. London: Thomas Snodham.

Houliston V (2007) Catholic Resistance in Elizabethan England: Robert Persons's Jesuit Polemic, 1580-1660. Aldershot: Ashgate.

Huntley FL (1964) Macbeth and the Background of Jesuitical Equivocation. PMLA 79(4): 390-400.

Ireland T (1610) The Oath of Allegiance, Defended by a Sermon Preached at a Synode in the Metropoliticall Church of Yorke. London: Nicholas Okes.

James T (1612) The Jesuits Downefall, Threatned against them by the Secular Priests for their Wicked Lives, Accursed Manners, Hereticall Doctrine, and More Then Matchiavillian Policie. Oxford: Joseph Barnes.

King J (1608) A Sermon Preached at White-Hall the 5. Day of November. Ann. 1608. Oxford: Joseph Barnes.

Kirwan C (1979) Aristotle and the So-Called Fallacy of Equivocation. The Philosophical Quarterly 29(114): 35-46.

Lake A (1640) Ten Sermons upon Severall Occasions, Preached at Saint Pauls Crosse, and Elsewhere. London: Thomas Badger.

Lake P (1989) Anti-Popery: the Structure of a Prejudice. In Cust R and Hughes A (eds) Conflict in Early Stuart England: Studies in Religion and Politics, 1603-1642. Harlow: Longman, pp. 72-106.

Lake P (2006) Anti-Puritanism: The Structure of a Prejudice. In Fincham K and Lake P (eds) Religious Politics in Post-Reformation England: Essays in Honour of Nicholas Tyacke. Woodbridge: Boydell Press, pp. 80-97.

Lily P (1619) Two Sermons viz. 1. A Preservative Lilie to Cure Soules. And 2. How to Seeke to Finde Christ. London: Thomas Snodham.

Lynde H (1629) Via Tuta: The Safe Way: Leading all Christians, by the Testimonies, and Confessions of our Best Learned Adversaries, to the True, Ancient, and 
Catholike Faith, now Professed in the Church of England. London: Felix Kingston.

Maloney TS (1984) Roger Bacon on Equivocation. Vivarium 22(2): 85-112.

Marotti AF (2005) Religious Ideology and Cultural Fantasy: Catholic and AntiCatholic Discourses in Early Modern England. Notre Dame, IN: University of Notre Dame Press.

Milton A (1995) Catholic and Reformed: The Roman and Protestant Churches in English Protestant Thought, 1600-1640. Cambridge: Cambridge University Press.

Morton T (1605) An Exact Discoverie of Romish Doctrine in the Case of Conspiracie and Rebellion by Pregnant Observations: Collected (not without Direction from our Superiours) out of the Expresse Dogmaticall Principles of Popish Priests and Doctors. London: Felix Kingston.

Morton T (1610) The Encounter against M. Parsons, by a Review of his Last Sober Reckoning, and his Exceptions Urged in the Treatise of his Mitigation, volume 2. London: William Stansby.

N S (1621) An Appendix to the Antidote. St Omer: English College Press.

Pagitt E (1635) Christianographie, or the Description of the Multitude and Sundry Sorts of Christians in the World not Subject to the Pope. London: Thomas Paine and William Jones.

Persons R (1585) A Christian Directorie Guiding Men to their Salvation. Rouen: Fr Parsons' Press.

Persons R (1607) A Treatise Tending to Mitigation towardes Catholike-subjectes in England. St Omer: F Bellet.

Persons R (1609) A Quiet and Sober Reckoning with M. Thomas Morton Somewhat Set in Choler by his Adversary P. R. St Omer: English College Press.

Persons R (1612) A Discussion of the Answere of M. William Barlow, D. of Divinity, to the Booke Intituled: The Judgment of a Catholike Englishman Living in Banishment for his Religion $\Xi^{2}$. St Omer: English College Press.

Pickford J (1618) The Safegarde from Ship-wracke, or Heavens Haven Compiled by J. P. Priest. Douai: Peter Telu.

Prynne W (1642) A Pleasant Purge, for a Roman Catholike, to Evacuate his Evill Humours. London: R. C.

Questier MC (1996) Conversion, Politics, and Religion in England, 1580-1625. Cambridge: Cambridge University Press.

Rogers H (1638) The Protestant Church Existent, and their Faith Professed in All Ages, and by Whom: with a Catalogue of Councels in All Ages, who Professed the Same. London: Richard Badger and Marmaduke Parsons.

Sanderson T (1611) Of Romanizing Recusants, and Dissembling Catholicks. London: Thomas Purfoot.

Schreiner S (2010) Are You Alone Wise? The Search for Certainty in the Early Modern Era. Oxford: Oxford University Press.

PERICHORESIS 13.1 (2015) 
JOSHUA RODDA

Sheldon R (1612) The Motives of Richard Sheldon Pr. for his Just, Voluntary, and Free Renouncing of Communion with the Bishop of Rome, Paul the 5. and his Church. London: William Hall and William Stansby.

Squire J (1618) A Sermon Preached at Hartford Assises, March 14. 1616. London: T. S.

Univocè-Catholicus (1607) Lucta Jacobi. London: Thomas Creede.

Waferer M (1634) An Apologie for Daniel Featley, Dr. in Divinitie, against the Calumnies of one S.E. in Respect of his Conference had with Doctor Smith, since Intituled by the Pope, Bishop, of Chalcedon, Ec. Concerning the Reall Presence. London: John Dawson.

Wake P (2011) 'A Monster Shapeless': Equivocation and the Treasonous Imagination. Textual Practice 25(5): 941-960.

Walker G (1641) A Defence of the True Sence and Meaning of the Words of the Holy Apostle, Rom. chap. 4. ver. 3, 5, 9. London: S. N.

Walkington T (1608) Salomons Sweete Harpe: Consisting of Five Words, like So Many Golden Strings, Toucht with the Cunning Hand of his True Skill, Commanding All Other Humane Speech: wherein both Cleargie and Laitie may Learne how to Speake. Cambridge: Cantrell Legge.

Walpole M (1613) A Treatise of Antichrist. St Omer: English College Press.

Walsham A (2009) 'This Newe Army of Satan': The Jesuit Mission and the Formation of Public Opinion in Elizabethan England. In Lemmings D and Walker C (eds) Moral Panics, the Media and the Law in Early Modern England. Basingstoke: Palgrave Macmillan, pp. 41-62.

Whitaker W (1606) An Answere to the Ten Reasons of Edmund Campian the Jesuit, in Confidence wherof he Offered Disputation to the Ministers of the Church of England, in the Controversie of Faith. London: Felix Kingston.

Wotton A (1608) A Trial of the Romish Clergies Title to the Church: by Way of Answer to a Popish Pamphlet Written by one A.D. and Entituled A Treatise of Faith, wherein is Briefly and Plainly Shewed a Direct Way, by which Every Man may Resolve and Settle his Mind in all Doubts, Questions and Controversies, Concerning Matters of Faith. London: Richard Field. 